\title{
Capsular Warning Syndrome-Better Observation or a New Disease?
}

\author{
Prakash R Paliwal ${ }^{1}$ and Vijay K Sharma ${ }^{1} 2^{*}$ \\ ${ }^{1}$ Division of Neurology, National University Hospital, Singapore \\ ${ }^{2}$ Yong Loo Lin School of Medicine, National University of Singapore, Singapore
}

*Corresponding author: Dr. Vijay K Sharma, Division of Neurology, Department of Medicine, National University Hospital 5 Lower Kent Ridge Road, Singapore 119074 , Tel: 65-67724126; Fax: 65-68723566; E-mail: drvijay@singnet.com.sg

Received date: Aug 11, 2014, Accepted date: Aug 12, 2014, Published date: Aug 18, 2014

Copyright: (c) 2014 Prakash RP, et al. This is an open-access article distributed under the terms of the Creative Commons Attribution License, which permits unrestricted use, distribution, and reproduction in any medium, provided the original author and source are credited.

Keywords: Acute ischemic stroke; Intracranial collaterals; Cerebral perfusion

\section{Capsular Warning Syndrome-Better Observation or a New Disease?}

Capsular warning syndrome (CWS) is the occurrence of at least three transientischemic attack (TIA) like episodes within 24 hours. The attacks are stereotypic and lack features of cortical dysfunction [1]. The presumed mechanism is angiopathy of a lenticulostriate artery. This syndrome is associated with a high risk (up to $40 \%$ ) of developing a completed stroke despite antithrombotic therapy [2]. Recently, some cases were noted to have a pontine infarct $[3,4]$, giving rise to the new term pontine warning syndrome, secondary to the occlusion of a penetrating branch of the basilar artery [5].

Usually, 4-15 lenticulostriate arteries arise from each middle cerebral artery (MCA). However, some patients have a single dominant lenticulostriate artery, predisposing these patients to an increased risk of developing CWS due to relatively poor collateral flow [6]. Other mechanism for CWS are artery to artery embolization, vasospasm, peri-infarct depolarization and atherosclerotic disease of the MCA $[7,8]$. Patients with CWS present with recurrent stereotypical transient clinical events. Most common manifestations are pure motor hemiparesis or ataxic hemiparesis with or without dysarthria. Clinical fluctuations are often observed during first few days before developing permanent deficits. These patients have usual vascular risk factors, hypertension being the commonest.

Neuroimaging studies often demonstrate relevant abnormal findings. Staff et al. described abnormal magnetic resonance imaging (MRI) in 7 out of their 8 patients with CWS [9]. Similarly, almost all patients with pontine warning syndrome demonstrate a paramedian pontine infarction [4]. Basilar artery stenosis and dolichoectasia have been described in a fair proportion of patients. High resolution MRI has been employed recently to demonstrate walls and the plaques in intracranial arteries in patients with CWS [10].

There is no conclusive data on the optimal management of patients with CWS. Antiplatelet agents, heparin, pressure therapy as well as thromobolytic agents have been used to treat patients with CWS [11-15]. It remains uncertain whether any of these therapeutic strategies alter the natural history of this interesting syndrome. Fahey et al. showed that loading dose of clopidogrel may be beneficial in aspirin-resistant CWS patients [11]. Intravenous thrombolysis with tissue plasminogen activator (IV-tPA) has also been studied in patients with CWS [15]. IV-tPA administered within 3 hours of the newest episode of CWS with National Institute of Health Stroke Scale (NIHSS) score of more than 7 points led to complete recovery in 3 out of the 4 cases. Interestingly, no abnormalities were noted in the MRI scans of the brain. One patient developed a new motor weakness (NIHSS score $=12$ ) after remaining asymptomatic for 10 hours after thrombolysis and MRI showed a new subcortical ischemic infarction.

In summary, CWS is a syndrome characterized by recurrent steroptypic transient ischemic deficits that have a high risk of progressing to a completed ischemic stroke. Internal capsule and pons are the commonest sites of ischemic insult. Although, no definitive treatment recommendation exist, urgent loading dose of antiplatelet agents may be beneficial. IV thrombolysis may be considered in patients presenting with a prolonged clinical event and within the therapeutic window.

\section{References}

1. Donnan GA, O'Malley HM, Quang L, Hurley S, Bladin PF (1993) The capsular warning syndrome: pathogenesis and clinical features. Neurology 43: 957-962.

2. Donnan GA, O'Malley HM, Quang L, Hurley S (1996) The capsular warning syndrome: The high risk of early stroke. Cerebrovasc Dis 202-207.

3. Farrar J, Donnan GA (1993) Capsular warning syndrome preceding pontine infarction. Stroke 24: 762.

4. Muengtaweepongsa S, Singh NN, Cruz-Flores S (2010) Pontine warning syndrome: case series and review of literature. J Stroke Cerebrovasc Dis 19: 353-356.

5. Fisher CM, Caplan LR (1971) Basilar artery branch occlusion: a cause of pontine infarction. Neurology 21: 900-905.

6. Aydin IH, Takci E, Kadioglu HH, Kayaoglu CR, Tuzun Y (1996) The variations of lenticulostriate arteries in the middle cerebral artery aneurysms. Acta Neurochir (Wien) 138: 555-559.

7. Hervé D, Gautier-Bertrand M, Labreuche J, Amarenco P; GENIC Investigators (2004) Predictive values of lacunar transient ischemic attacks. Stroke 35: 1430-1435.

8. Lee J, Albers GW, Marks MP, Lansberg MG (2010) Capsular warning syndrome caused by middle cerebral artery stenosis. J Neurol Sci 296: 115-120.

9. Staaf G, Geijer B, Lindgren A, Norrving B (2004) Diffusion-weighted MRI findings in patients with capsular warning syndrome. Cerebrovasc Dis 17: $1-8$.

10. Zhou L, Ni J, Xu W, Yao M, Peng B, et al. (2014) High-resolution MRI findings in patients with capsular warning syndrome. BMC Neurol 14: 16.

11. Fahey CD, Alberts MJ, Bernstein RA (2005) Oral clopidogrel load in aspirin-resistant capsular warning syndrome. Neurocrit Care 2: 183-184.

12. Kawano H, Nakajima M, Inatomi Y, Yonehara T, Ando Y2 (2014) Loading dose of clopidogrel in combination with other antithrombotic therapy for capsular warning syndrome. J Stroke Cerebrovasc Dis 23: 1265-1266.

13. Dobkin BH (1983) Heparin for lacunar stroke in progression. Stroke 14: 421-423.

14. Lalive PH, Mayor I, Sztajzel R (2003) The role of blood pressure in lacunar strokes preceded by TIAs. Cerebrovasc Dis 16: 88-90. 
Citation: Paliwal PR, Sharma VK (2014) Capsular Warning Syndrome-Better Observation or a New Disease?. Brain Disord Ther 3: e113. doi: 10.4172/2168-975X.1000e113

Page 2 of 2

15. Vivanco-Hidalgo RM, Rodriguez-Campello A, Ois A, Cucurella G, PontSunyer C, et al. (2008) Thrombolysis in capsular warning syndrome. Cerebrovasc Dis 25: 508-510. 